\title{
The Law of Criminal Procedure in The Contention between Liberality and Prodigality
}

\author{
WILLIAM DEAN
}

The law consciousness ${ }^{1}$ of Elizabethan society is variously reflected in the drama of the time, but it is odd that, while there are many references in individual plays to aspects of the criminal law and while many crimes are portrayed with imaginative energy or with keen insights into the criminal mentality, there are few stage representations of the processes of the criminal law where major crime is concerned. For example, nowhere in Shakespeare's plays is an English jury trial depicted ${ }^{2}$ although other kinds of trials revealed possibilities for spectacular and colourful staging, as well as those of psychological tension arising out of the conflicts of will between the defendant and his accusers. ${ }^{3}$ But the technicality of the English criminal law remained substantially ignored. Nevertheless, there are some plays which do attempt presentation of this kind of matter. The Tudor interlude Nice Wanton ${ }^{4}$ (ca. 1550) shows a jury returning to deliver its verdict of "guilty" in a trial for murder. The Elizabethan play A Warning for Faire Women $^{\text {s }}$ (t.p. 1599) traverses some of the law and procedure related to the crimes of murder and conspiracy to murder. But the most comprehensive representation of the whole procedure of the criminal law from discovery of the commission of the crime to sentence of the murderer is The Contention between Liberality and Prodigality ${ }^{6}$ (t.p. 1602).

This play is described on the title page as "a Pleasant comedie"; but in adherence to archaic forms of emblematic staging ${ }^{7}$ to issue forth much of its moral matter it really is a didactic entertainment which sets out the consequences of the immoderate handling of money. Whether it was an allegory of political economy designed to instruct the Queen in the necessity of reasonable liberality in her fiscal policies ${ }^{8}$ is more difficult of persuasive proof. The immoderate characters are "couetous Tenacity" (1.416) who is eventually murdered by "wastefull Prodigality" (1.415). Both these characters "most humbly make their suites for money" (1.418) unto the goddess Fortune who entrusts her son, Money, first to the care of Prodigality. Money is cruelly mishandled; but, even though physically reduced, he eventually manages to escape from Prodigality and his "thriftlesse, Roysting company" (1.744) and returns to his mother. Fortune 
then assigns him to Tenacity. Yet Tenacity also mistreats him by denying him any exercise at all and even keeps him "lockt. ..vp in coffers, or in bags bound. . fast" (1.1183) so that he becomes fat, sluggish and sickly. Meanwhile, angered at what he takes to be Fortune's capricious treatment of him, Prodigality tries to recover Money. With his companions he makes an assault on Fortune's castle, trying to scale the walls by means of a ladder so as to force entry through a window. However, "Fortune claps a halter about his neck, he breaketh the halter \& falles" (11.903-904, S.D.). Outraged at this insult to her dignity, Fortune vows that Prodigality "shall arriue vnto a wretched end" (1.949). This vow is fulfilled when Prodigality and his companions, Tom Tosse and Dick Dicer, pursue Tenacity, overtake him, and then attack and kill him. Money is robbed from him. At this point in the action, the law of criminal procedure, which can be divided into three major stages, is brought into play. The first stage, after discovery of the murder, involves the investigative process and the apprehension of Prodigality; the second is concerned with preliminary inquiry in to the facts and circumstances of the case and is completed with the indictment of the suspect; the third is the trial and sentence of the accused.

The murder is discovered by the constables who, according to the stage direction, "make hue and cry," and this they do by clamouring, "Theeues, neighbors, theeues, come forth, beset the country" (1. 1043). The procedure thus set in motion is one of the oldest in English criminal law. ${ }^{9}$ When a person discovered that a felony had been committed it was incumbent on him to raise the hue and cry, and neighbours when roused were. bound to assist in the pursuit and discovery of the felon. If necessary the hue and cry could be pursued from parish to parish and each parish, when raised, was under an obligation to join in. This procedure was followed until the suspect was apprehended. In De Republica Anglorum, Sir Thomas Smith summarises the procedure after a person reports the commission of a robbery:

The Constable of the village to whom he doth come, and so make that crie, ought to raise the parish to aide him and seeke the theefe, and if the theefe be not founde in that parish, to go to the next and raise that Constable, and so still by the Constables and them of the parish one after an other. ${ }^{10}$

A similar procedure applied on discovery of a murder. Penalties attached to any person or parish not observing the duty to join in and the law relating to penalties incurred by negligence in pursuit was strengthened by statute, 27. Eliz. c.13 (1584-85). The general law was that even an ordinary person, and not only the constable or sheriff, "was bound to arrest on suspicion when the hue and cry had been raised." 11

In Liberality and Prodigality the raising of hue and cry is shown in action; but the playwright has not presented an idealised version of the efficiency of the system. Prodigality and his companions hear the cry and see the constables enter in pursuit. Then they "stand backe, lie close, and 
let them passe by" (1. 1048). The host of the inn, at which Prodigality has been a favoured customer, is roused by the cry of the constables and his first question, when he confronts them, is, "Where dwell these Constables?" (1. 1051). Such a question would seem to imply that the hue and cry is being pursued out of the original parish in which the crime was committed. In fact the question is a diversionary tactic on the host's part to gain time so that the criminals can make good their escape. In an aside, the host urges, "Dick, Tom, Will, ye hoorsons, make ye all ready, and haste a pace after" (1. 1056), ${ }^{12}$ and to delay the pursuit he has the constables explain the events which have led to hue and cry being raised. This incident, small though it is, indicates that the effectiveness of hue and cry is dependant on the cooperation of all in the community and further indicates that in the world of roguery others besides the actual criminal have something to gain from crime. In the Host's case it is the free-spending at his taverns which had been indicated earlier in the play. ${ }^{13}$

The ruse is not entirely successful, for subsequently the Sheriff informs Virtue of the details of the robbery and murder committed by Prodigality and that

The country hereupon rais'd hue and cry streightway:

$\mathrm{He}$ is apprehended, his fellowes fled away:

I supplying, though vnworthy, for this yere,

The place of an Officer, and Sherife of the shiere,

To my Prince's vse, haue seyzed on his mony,

And bring you the same, according to my duty.

(11. 1162-1167)

The sheriff, who was appointed for a year, was a principal conservator of the peace; but whereas the constable "represented and acted as the executive agents of the hundred and township,"14 the sheriff"s primary duty involved attention to execution of all the royal writs and it was he who set in motion the complicated machinery of the royal courts of justice. The sheriff had also a special duty to arrest suspected felons and to seize the goods suspected of having been stolen. Such goods were forfeit "being waived or left by a Felon in his Flight, from those who either actually do pursue him, or are apprehended by him so to do, whereby he forfeits the Goods so waived, whether they be his own proper Goods, or the Goods of others stolen by him, which shall not be restored to the right Owners but upon a proper Prosecution." 15 Money is then given in charge to Liberality, who is in effect a fiscal authority, of the Crown, for proper handling and use.

After Virtue is informed of the several crimes she orders Equity to

examine more diligently,

The maner of this outragious robbery:

And as the same, by examination shall appeare,

Due iustice may be done in presence here. 
In tracing the transformation in English drama of the character, Justice, from a theological virtue to an equitable presence in the legal order, J. Wilson McCutchan ${ }^{16}$ draws attention to this passage and observes that Equity has now acquired the function of a civil authority who arrests and effects the arraignment of Prodigality. The bias of McCutchan's argument is that the presence of Equity reflects the late sixteenth-century concern that the rigours of the common law should be modified by this personification of conscience. I think, however, that this bias is misplaced.

The jurisdictional conflict between the common law courts and chancery did not involve the criminal law, although (in the development of criminal law) general and not "legal" notions of equity were pervasive in modifying the application of harsh sentences. ${ }^{17}$ Furthermore Equity as a jurisprudential concept did not stand apart from other concepts within the legal order. The definition of the boundaries of equity is difficult to locate but the following description by Rastell, who delineates two sorts of Equity, indicates, in general terms, an understanding of the notion in the sixteenth century:

(i) Equitie is the correction of a law generally made, in that part wherin it faileth, which correction of the generall wordes, is much vsed in our law.

(ii) Equity is whe the wordes of the law are effectually directed and one thinge onely prouided by $\mathrm{y}^{\mathrm{e}}$ wordes of the lawe, to the end that al thinges of like kinde may be prouided by the same. ${ }^{18}$

Within the context of Liberality and Prodigality the presence of Equity as an officer involved in the proper functioning of the criminal law would appear to refer to this general belief that all judicial proceedings should be carried out with fairness. What is more important is that Equity is directed to "examine more diligently, The maner of this outragious robbery" for this is a clear reference to an important sixteenth-century development in the criminal law which is even now the foundation of the whole system of preliminary investigation of a person accused of having committed an offence.

Ancient English law and custom pertaining to juries was founded on the fact that juries decided on their own knowledge. ${ }^{19}$ With the growth of large settlements by the sixteenth century this principle had in reality become a legal fiction and the knowledge of juries had to be supplemented by other information. To meet this development there had arisen the practice whereby justices of the peace took examination of the accused and of witnesses before a jury was empanelled. By two important statutes, $1 \& 2$ Phil. \& Mary, c. 13 (1554) and $2 \& 3$ Phil. \& Mary, c. 10 (1555), these practices were statutorily recognized..$^{20}$ The former statute provided that before a person was admitted to bail on an accusation of manslaughter or felony the justices should

take the examination of the said Prisoner and information of them that bring him, of the fact and circumstances thereof, and the same, or as 
much thereof as shall be material to prove the felony, shall be put in writing. ${ }^{21}$

By $2 \& 3$ Phil. \& Mary, c. 10, the preliminary examination and the record of such examination were required where a person was committed on a charge of manslaughter or other felony. Both the examination of the accused and the deposition of witnesses were to be transmitted to the judges who would subsequently try the accused: "So soone as any is brought to the Iustices of peace by this hue or crie, by the Constable or anie other who doth pursue the malefactor, he doeth examine the malefactor, and writeth the examination and his confession." 22

The witnesses were bound in their own recognizances "to be at the next sessions of gaole deliuerie to giue their euidence for the Queene." 33 The examination and the material evidence of the witnesses were used to supplement the knowledge of the grand jury when the indictment was preferred against the accused. Of course, if no grounds for suspicion were found by the justice the matter ended there and then. In Liberality and Prodigality, however, Equity reports "That Prodigality is guiltie of the fact, no doubt" (1. 1239). Equity, then, by virtue of the order to examine Prodigality, is shown to be a Justice of the Peace carrying out duties imposed by the Marian statutes. With his report of the findings of the examination, the second major stage in the legal procedure is complete.

The action of the play moves directly from Equity's finding to the trial of Prodigality. The playwright, doubtless for dramatic economy, has chosen to suppress other incidents of procedure, although the trial itself necessarily assumes them. We can, for completeness, imagine the following sequence of events. ${ }^{24}$ Immediately on taking examination of Prodigality and testimony of the witnesses, Equity has referred particulars of the alleged robbery and murder to a clerk who has drawn an indictment. The witnesses were then sworn and the indictment was then laid before the grand jury who examined the witnesses. It having appeared to a majority of the jury (that is at least twelve, for there were twenty-three grand jurors) that Prodigality had committed the crimes alleged against him, a billa vera or true bill was found and so endorsed. The indictment was then returned to the clerk of the court. Indictments for felonies were tried at the same assizes or sessions at which they were preferred to and found by the grand jury. If the defendant against whom the indictment was found was in court, or in the custody of the court, he could immediately be arraigned on the indictment without any previous process. It is to this aspect of the law that reference is made in two related passages in Liberality and Prodigality. The first occurs when the tipstaff announces,

Roome, my Masters, giue place, stand by.

Sir, Equity hath sent me to let you vnderstand,

That hither he will resort out of hand,

To sit vpon the arraignement of Prodigality.

(11.1232-1235) 
The second occurs when Equity enters and tells the assembled company

That Prodigality is guiltie of the fact, no doubt.

And therefore for furtherance of Iustice effectually,

My Lord the Iudge comes to sit vpon him presently:

Wherein we craue your assistance.

$$
\text { (11.1239-1242) }
$$

The judge forthwith enters and Prodigality is arraigned.

Thorp's confusion, corrected by McCutchan, ${ }^{25}$ that Equity presides at the trial is probably referable to the information that Equity will "sit vpon the arraignement" and in fact this is just what he does, but the trial is presided over by one of the justices of Queen's Bench. Nevertheless other judicial officers and even some of the gentry might sit with the judge. The description of Elizabethan trial procedure provided by Sir Thomas Smith is for the assizes, ${ }^{26}$ that is for trials held in one of the counties by a judge exercising power by virtue of the commissions of over and terminer and gaol delivery; but his description emphasises the spectacular and festive elements as well as the informality ${ }^{27}$ of Elizabethan trials in general. In Liberality and Prodigality "The Iudge [is] placed, and the Clerkes vnder him" (1 1. 1245-1246, S.D.). Smith gives a fuller description:

there is a tribunall or place of iudgement made aloft vpon the highest bench, there sitteth the two Iudges which be sent downe in Commission in the midst. Next them on eche side, sitteth the Iustices of peace, according to their estate and degree. On a lower bench before them, the rest of the Iustices of the peace, and some other gentlemen or their clarkes. ${ }^{28}$

This account of the disposition of the principal persons at a criminal trial differs slightly from that found at the Queen's Bench in Westminster Hall; ${ }^{29}$ the reference to Equity sitting on the arraignment of Prodigality and the stage direction for the placing of the judge, suggest that the dramatist had in mind that Equity, as a justice of the peace, should sit next to the judge just as justices of the peace did at the assizes. Indeed the whole disposition of characters on stage throughout the trial would appear to conform generally to Smith's account.

The arraignment of Prodigality, after the preliminary examination by Equity, is the next and perhaps most important step in the legal process. A person who had been indicted by a grand jury could not be released (except on bail) until he had been arraigned and tried at bar by a petty jury, because an indictment, which is a written accusation of a person by a grand jury, reflects the opinion, by the country in the form of the jury, of the accused. However, it is not a conviction and the guilt or innocence of the accused must be established by a petty jury. ${ }^{30}$ The arraignment consists of three parts ${ }^{31}$ (i) calling the prisoner to the bar by name; (ii) reading the indictment to him in English; and (iii) asking whether or not he is guilty of the offence charged. Each of these three steps is presented in the trial of Prodigality. The judge orders the clerk to call the prisoner 
and this is done with all the formality of the law. The clerk transmits the judge's instructions to the crier who duly repeats them and calls for Prodigality to be brought forth. The Sheriff, who has Prodigality in his charge, delivers him to the court and the clerk then instructs, "Prodigality, hold vp thy hand" (1. 1259). This is a reference to the old and longcontinued practice whereby the prisoner was required to hold up his hand so as more completely to identify himself as the person named in the indictment. ${ }^{32}$

As soon as identification has been established, the indictment is read to Prodigality. To make for ease of reference I transcribe it in full:

Thou are indited here by the name of Prodigality, for that thou, the fourth day of February, in the three \& fortie yeere of the prosperous raigne of Elizabeth our dread Soueraigne, by the grace of God, of England, France, and Ireland Queene, defender of the faith, \&c. together with two other malefactors yet vnknowne, at High-gate in the County of Middlesex aforesaid, didst felloniously take from one Tenacity of the parish of Pancridge yeoman, in the said County, one thousand pounds of gold and siluer starling: And also, how thy selfe, the said Prodigalitie, with a sword, price twenty shillings, then and there cruelly didst giue the saide Tenacitie vpon the head, one mortall wound, whereof hee is now dead, contrarie to the Queenes peace, her Crowne and dignitie.

\section{(11.1260-1271)}

Although indictments were entered and enrolled in Latin, they had to be read to the defendant in English by virtue of the Statute of Pleadings $(37$ Ed. 3,15$))^{33}$ The extreme learning which attended the necessity for precision in the language of indictments is properly considered in relation to the Latin forms. Nevertheless, the English version also reflects the following concerns noted by Holdsworth: "the formality, certainty, and verbal precision required in an indictment has always been one of the most salient characteristics of English criminal procedure." ${ }^{34}$ In the light of this observation we can see the degree to which the dramatist has tried to colour his stage indictment with legal realism and my remarks relating to the wording of the indictment are made in light of the expositions of the law in the several commentaries of Hale, Hawkins and Archbold. ${ }^{35}$ Prodigality's name is truly stated for there had to be certainty as to the person who had been indicted. The general rule is satisfied in the play, but it perhaps should be noted that there is no attempt to indicate an "addition" to Prodigality's name of his "estate, degree, or mystery," as required by the Statute of Additions ( 1 H. 5 cap. 5). The indictments in A Warning for Faire Women show additions: "George Browne, late of London Gentleman" is indicted for the murders of "George Sanders Gentleman, and Iohn Bean yeoman" and "Anne Sanders, and Anne Drurie, late of London Spinsters, \& . . Roger Clement, late of the same yeoman"36 are indicted as accessories before and after the murder of George Sanders. 
In Liberality and Prodigality the fact that Prodigality is a personification of a moral defect presumably obviated the need for such legal precision, but this quality of indictments is otherwise reflected. The person against whom an offence was alleged to have been committed had also to be identified with particularity and so we find the victim described as "one Tenacity of the parish of Pancridge yeoman, in the said County."

The commencement of an indictment had also, and importantly, to set forth a statement of venue and hence it is alleged in the indictment that Prodigality committed the felonies "in the County of Middlesex." The indictment had to indicate the venue of the crimes so as to establish that the court, before which the accused was to be tried, had jurisdiction by virtue of its commission. The ancient law assumed that the jurisdiction of the court and the knowledge of the grand jury by which it was informed were coextensive and the offence had to have been committed within the limit specified by the venue. It is within this general rule of venue that we also find it alleged that Tenacity was robbed at Highgate in the said county, and, in conformity with the rules applicable to "special venue," we find that every material act mentioned in the indictment is referable to such a place. The special venue was usually effected by introducing the words "then and there" after every averment subsequent to the first. Hence, after the indictment for robbery, it is averred that Prodigality "then and there cruelly didst giue the saide Tenacitie vpon the head, one mortall wound."

In addition to certainty as to place, there had also to be certainty as to the time of the offences and this was normally laid as to the day, month and year on which they were supposed to have been committed. It was usual, though not necessary, to insert the regnal year. Thus the time alleged in the present indictment is "the fourth day of February, in the three \& fortie yeere of the prosperous raigne of Elizabeth our dread Soueraigne." It is perhaps worth noting that this is the date on which the robbery and murder are alleged to have been committed, and not the date of the trial as stated by W.W. Greg in the introduction to the Malone Society reprint of the play. ${ }^{37}$ This point would be of little moment except that Greg assumes that the date of the trial might indicate the date of performance at Court. The date in the indictment presumably refers to time before the trial and it is difficult to sustain conjectures on a possible performance date from this reference alone.

For an indictment to be good, the offences had to be charged positively, that is directly to affirm that the defendant did the acts alleged and all the facts and circumstances constituting the offence had also to be laid positively. This principle is in part reflected in the concern for verbal precision and also in the necessity, in indictments for some offences, that technical words be properly set forth. Hence felonies had to be alleged to have been done "feloniously" while robbery required that the accused 
be charged, among other things, with "feloniously stealing taking and carrying away." In cases of murder it was necessary to allege that the accused feloniously and of malice aforethought murdered the deceased. An indictment for a felony which omitted the word "feloniously" was voided and so were those which omitted technical expressions.

The indictment against Prodigality reveals an awareness by the dramatist of the general requirements of certainty and verbal precision. Thus it is alleged that Prodigality "didst felloniously take... one thousand pounds of gold and siluer starling." Not only is there the technical word alleging felony, but there is also precise reference to the nature of the money taken. It was a rule that money had to be described as so many pieces of gold, silver, or other lawful tender, and the species had to be identified. ${ }^{38}$ Such was the need for precision and certainty that even the value of the instrument by which the murder was done ought to be set forth. ${ }^{39}$ Thus it is further averred that the said Prodigalitie, with a sword, price twenty shillings, then and there cruelly didst giue the said Tenacitie vpon the head, one mortall wound, whereof hee is now dead. And furthermore, averments must establish a necessary causality between the material facts and the legal offence. This kind of precision is also reflected in the conclusion to the indictment when it is alleged that the actions complained of, which were offences at common law, were done "contrarie to the Queenes peace." Although it was usual to add the further words, "her Crowne and dignitie," they were not essential for the indictment to be good.

In general, therefore, we can say that the playwright had sufficient knowledge of the law relating to the drawing of indictments to prefer one against Prodigality which in the context of performance seemed fully to comply with the technical rules. This is, apart from the more formal terms, the case with the specific references to the several details attending the murder. Such specificity makes it all the stranger then that the indictment against Prodigality, while containing technical terms such as "feloniously," omits other expressions just as important in law. The most notable omission is the averment that Prodigality "murdered" Tenacity. However, the indictment generally reveals an awareness of the need for certainty and verbal precision required in the actual law and this is sufficient to indicate the realism of legal procedure on stage.

After the indictment has been read to Prodigality, the next step in the arraignment is to ask him, "How saist thou, Prodigalitie, to this robberie, felonie, and murther? art thou guiltie, or not guiltie"? (11.1272-1273). ${ }^{40}$ Instead of pleading immediately, he first asks the judge "graunt me councell to plead my cause" (1. 1274) but this is refused because, as the judge explains, "it standeth not with our lawes" (1.1275). Prodigality next asks for a "respite," that is an adjournment from the need to plead immediately to the indictment. This request is also refused. The reasons for these refusals may be explained as follows. Under the old law of criminal pro- 
cedure the "written indictment was in form and in fact a presentment tc the king on which the king took action." 41 The written indictment was therefore for the record of the royal courts of justice and not the prisoner He was only entitled to have it read to him when he was arraigned so tha he could plead to it and such pleading had to be by himself alone and with out the benefit of counsel. ${ }^{42}$ This rule was ancient but Smith provides : contemporary Elizabethan understanding of its rationale:

he that by violence shall attempt to breake that peace and assurance, hath forfeited against the scepter and crowne of England: and therfore. . if any be found by the xii. men to haue offended... the prince is saide to be partie, and he that shall speake for the prisoner shall be rebuked, as speaking against the prince. ${ }^{43}$

The effect of such a rule was that the prisoner had to defend himsell orally as best he could.

Confronted with the need to plead to his arraignment forthwith and without benefit of counsel, Prodigality does not prolong the trial. He con. fesses, and this obviates the need to empanel the petty or trial jury to try the case. But before giving the sentence of the court, the judge asks,

Then what canst thou say for thy selfe, Prodigalitie,

That according to the law thou shouldst not die?

(11. 1285-1286)

Prodigality has nothing to say in arrest of judgement and is content to appeal "to the Princes mercy" (1. 1287). In accordance with court procedure, the judge then rehearses the salient features of the indictment and arraignment and then pronounces sentence of death in conformity with received practice: ${ }^{44}$

I ludge thee, to be had from hence, to the place thou camst fro, and from thence to the place of execution, there to be hangd till thou be dead. God haue mercy on thee.

$$
\text { (11. 1292-1295) }
$$

The death sentence in Liberality and Prodigality does not include gibbeting: that is hanging of the felon's corpse in chains till it rots. This was part of Daniel's sentence on Ismael in Nice Wanton and is part of the further pun. ishment ordered by the Council for George Browne in $A$ Warning for Fair Women. Sentence of death without further punishment is sufficient tc bring Prodigality to an acknowledgment of his previous vicious and sinfu life and to a realisation of the untrustworthiness of the goddess Fortune After these affirmations of repentance, Prodigality appeals for roya clemency. The judge agrees to this request telling Prodigality that

for you to the Prince, there shall be made Petition, That though your punishment be not fully remitted, Yet in some part, it may be qualified. 
Since the play was performed at Court, it is not fanciful to imagine that such pardon was granted to Prodigality at the end of the performance by Elizabeth herself.

In discussing Liberality and Prodigality Thorp remarks that it "closes with a very merry mock trial. Nevertheless, in spite of its comic opera tendencies, Liberality and Prodigality is really a morality play." 45 There is really not much to object to in this opinion, except perhaps to wonder what is meant by "mock trial." The consequences of avarice and prodigality have been amply shown. Those characters who seek to gain wealth through crime will be punished by the law. And like many legal entertainments over the centuries, there is a pervasive sense of informality and even festivity in the proceedings. Yet the procedures shown are not in any way parodic of the legal system. If anything Liberality and Prodigality testifies to the efficiency and fairness of the English criminal law which is the means by which the Queen's peace is kept throughout the kingdom.

What is of importance in the play is that it does provide a dramatisation of all the principal steps in the law of criminal procedure. Hawkins notes that "The first Thing to be done in order to the bringing a Criminal to Justice is to arrest him." 46 And this is where the legal action in the play starts from. Process in respect of the Indictment is next shown and then the arraignment, trial and judgement. The interests of the anonymous dramatist were more technical than is usual in Elizabethan plays of roguery and murder; but in his concern with the processes by which a criminal was apprehended and tried, he really reflects another aspect of vicarious enjoyment to be derived from reports of cruel and bloody murders. From the sensational reports in chap-books of "especially gruesome murders, often involving dismemberment or burning" 47 to the finer psychological studies of the great Elizabethan dramatists there is a continuum of interest in the spectacle of crime and in the complexities of the criminal imagination. In the chap-books as elsewhere, there is some interest in the manner by which criminals were apprehended and punished. There is nothing sensational about the murder in Liberality and Prodigality and nothing exciting about the process of arrest. What we do have is an interest and enjoyment in that technical part of the criminal law which necessarily complement more popular taste.

\section{University of Otago}

\section{Notes}

1 E.W. Ives, "The Law and Lawyers," in Shakespeare Survey 17: Shakespeare in His Own Age, ed. Allardyce Nicoll (Cambridge, 1964), p. 73.

2 Ibid., p. 86. 


\section{0 / Renaissance and Reformation}

3 One thinks, for example, of The Merchant of Venice (although strictly Shylock is the accuser) or the trial of Byron in The Tragedy of Charles, Duke of Byron.

4 Nice Wanton: an Unrecorded Edition (1906), ed. John S. Farmer, Tudor Facsimile Texts (for Subscribers, London \& Edinburgh, 1907).

5 A Warning for Faire Women, 1599, ed. John S. Farmer, Tudor Facsimile Texts (for Subscribers [London], 1912).

6 The Contention between Liberality and Prodigality, ed. W.W. Greg, Malone Society Reprints (Oxford, 1913). All line references are to this edition.

7 The feathered Vanity, the retiring Virtue and even Fortune in a chariot drawn by four kings, despitc the Marlovian style, are indicative of such a tradition. There are of course also realistic scenes.

8 Cf. Peter J. Houle, The English Morality and Related Drama (Hamden, Conn., 1972), p. 66.

9 Sir Matthew Hale, Historia Placitorum Coronae, 2 vols., ed. P.R. Glazebrook, Classical English Law Texts (London, 1736; repr. Professional Books, London, 1971), II, 98-104. Hereafter cited as Hale, Plac. Cor.

10 Sir Thomas Smith, De Republica Anglorum (London, 1583; repr. Scolar Press, Menston, 1970), Lib 2, chap. 20, p. 71.

11 Sir William Holdsworth, A History of English Law, 16 vols. (London, 1903-1966), IV, 522. Hereafter cited as H.E.L.

12 Will does not otherwise appear. Presumably an acting interpolation.

13 See 11. 97-105.

14 Holdsworth, H.E.L., IV, 123.

15 William Hawkins, A Treatise of the Pleas of the Crown:... In Two Books (London, 17241726; repr. Arno Press, N.Y., 1972), II, 451. Hereafter cited as Hawkins, P.C.

16 J. Wilson McCutchan, "Justice and Equity in the English Morality Play," Journal of the History of Ideas, 19 (1958), 405-10.

17 Generally see Holdsworth, H.E.L., IV, 280-81.

18 John Rastell, An exposition of certaine difficult and obscure wordes, and termes of the lawes of this Realme, The English Experience $\mathrm{N}^{\circ} .210$ (London, 1579; repr. Amsterdam \& N.Y. 1969), fols. $76^{\mathrm{r}}-77^{\mathrm{v}}$.

19 Holdsworth, H.E.L., IX, 137-38.

20 Sir James Fitzjames Stephen, A History of the Criminal Law of England, 3 vols. (London, 1883; repr. Burt Franklin, N.Y., n.d.), pp. 219-21; also Holdsworth, H.E.L., I, 296; and John H. Langbein, Prosecuting Crime in the Renaissance (Cambridge, Mass., 1974).

21 Quoted Langbein, Prosecuting Crime, pp. 10-11.

22 Smith, De Republica, Lib. 2, chap. 20, p. 72.

23 Idem.

24 J.F. Archbold, Pleading and Evidence in Criminal Cases, 16th ed. by William Bruce (London, 1867), pp. 69-70, 72, 87-88, hereafter cited as Archbold, is the source of the summary given

25 Willard Thorp, The Triumph of Realism in Elizabethan Drama 1558-1612, Princeton Studie in English, $N^{\circ} .3$ (Princeton, 1928), p. 6,; McCutchan, "Justice and Equity," 409.

26 Smith, De Republica, Lib. 2, chap. 23, pp. 75-84.

27 Holdsworth, H.E.L., IX, 225 notes the informality.

28 Smith, De Republica, Lib. 2, chap. 23, p. 77.

29 Cf. the description of Queen's (King's) Bench at Westminster Hall in Ives, "Law and Lawyers, p. 81, and see pl. X, between pp. 144-45. 
30 Smith, De Republica, Lib. 2, chap. 23, p. 76.

31 Hale, Plac. Cor., II, 219; Archbold, p. 134.

32 Hale, Plac. Cor., II, 219; Hawkins, P.C., II, 308.

33 Hawkins, P.C., II, 308.

34 Holdsworth, H.E.L., III, 616.

35 Hale, Plac. Cor., II, 165-193; Hawkins, P.C., II, 224-44; Archbold, pp. 22-61.

36 Sigs. Hiv $^{\mathrm{T}}$ and $\mathrm{Ii}^{\mathrm{T}}$.

37 Ed. Cit., p.v.

38 Archbold, p. 54; Stephen, Hist. Crim. Law, p. 282.

39 Hale, Plac. Cor., II, 185: "Regularly it ought to set down the price of the sword or other weapon, or else say nullius valoris, for the weapon is a deodand forfeited to the king. . But this seems not to be essential to the indictment."

40 Smith, De Republica, Lib. 2, chap. 23, p. 78; Hale, Plac. Cor., II, 219.

41 Holdsworth, H.E.L., III, 615.

42 Hale, Plac. Cor., II, 219.

43 Smith, De Republica, Lib. 2, chap. 9, pp. 50-51.

44 Smith, De Republica, Lib. 2, chap. 23, p. 83; Hale, Plac. Cor., II, 399.

45 Thorp, Realism, p. 6.

46 Hawkins, P.C., "An Analysis of the Second Book," unpaginated, after Index.

47 Langbein, Prosecuting Crime, p. 46. At pp. $45-54$ there is a full discussion of the chap-books relating them to investigative procedure. The illustrations between pp. $46-47$ indicate popular taste for the gruesome spectacle as well as just punishment. 